\title{
Recreational Program and Its Association with Job Satisfaction
}

\author{
Fadzilah Akmal $^{1}$, Fakhrul Anwar Zainol ${ }^{1}$, Maslina Mansor ${ }^{1} \&$ Zaharah Ghazali $^{1}$ \\ ${ }^{1}$ Faculty of Business Management \& Accountancy, Universiti Sultan Zainal Abidin, Terengganu, Malaysia \\ Correspondence: Fadzilah Akmal, Faculty of Business Management \& Accountancy, Universiti Sultan Zainal \\ Abidin, Gong Badak Campus, 21030 Kuala Terengganu, Terengganu, Malaysia. Tel: 60-9-668-8224. E-mail: \\ fadzilahakmal@unisza.edu.my
}

\author{
Received: April 1, 2012 Accepted: July6, 2012 Online Published: October 19, 2012 \\ doi:10.5539/ass.v8n13p172 URL: http://dx.doi.org/10.5539/ass.v8n13p172
}

The research is financed by University Grant, University of Sultan Zainal Abidin, Gong Badak Campus, 21030 Kuala Terengganu, Terengganu, Malaysia

\begin{abstract}
This article conceptually discussed recreational program, job satisfaction, and the relationship between both of them, the importance of recreational program and leisure satisfaction. Hence, it is essential to the organization to ensure; "does the recreational program contribute to job satisfaction?", "Does the recreational program could achieve organizational objectives?" and "what will be the contributions of running these programs?" The discussion indicates that recreational programs are known in a wide variety of forms of programs, and many published reported on the job satisfaction and recreational programs. Besides that, many fields of studies have been carried out primarily in health industries; however, lack of studies in services industries. The positive linkage of recreational and job satisfaction, and recreational and leisure satisfaction need to be proven in future research.
\end{abstract}

Keywords: job satisfaction, recreational program, leisure activities, leisure satisfaction, services industries

\section{Introduction}

Today, substantial number of recreational programs has been organized as one of additional benefits to corporate task force. Recreational programs acts as a stimulator towards any efforts carry out by organizations in a process of creating excellent task force. Additionally, recreational programs are purposely designed to boost morale, stimulate motivation, and increase or maintain job satisfaction. The quality of human capital now increasingly becomes the cutting edge of competitiveness. For these reasons, many studies explore job satisfaction from various perspectives. In fact, there are several studies on job satisfaction that purposely to examine variables that could affect job satisfaction directly and indirectly.

Having competent staff to deliver high quality products and services is critical in building customer confidence and goodwill, driving customer satisfaction, enhancing reputation, and ultimately realizing corporate vision and strategic goals. This is to ensure that the competence and professionalism of staff is further strengthened (Zeti Akhtar Aziz, 2005). A survey by The Aon Hewitt showed staff turnover rate in Malaysia was expected 13 percent, which was the second highest in Asean after Vietnam (Changsorn, 2010). Aon Hewitt said employees had tendencies to look for external opportunities; therefore, reestablish staff privileges would be the best way to retain staff. Thus, recreational programs or leisure activities have evolved as to fulfil the needs of the workers. Quinn (1998) found significant positive relationship between job satisfaction, leisure satisfaction and psychological health, which the higher levels of satisfaction in work or leisure, the greater levels of psychological health. Thus, workers gained satisfaction from leisure activities; it appears to be economically logic to consider how to enhance job satisfaction through leisure activities and recreational programs.

In Malaysia, several programs that frequently being implemented are annual sports day, family day, annual dinner, and travel. Quite a few of giant corporations own private property such as bungalow, chalet, apartment, and sports and recreational centre for the use of their employees for leisure activities; for example, banking institutions, TNB, F\&N, and the Malaysian government. Since all the recreational and leisure activities engage substantial amount of investment, it is a tremendous challenge and critically needed for management to identify and plan which of those activities could produce the highest impact on its employee awareness and satisfaction 
towards their jobs.

\section{Recreational Program}

\subsection{What Is a Recreational Program?}

Recreational programs are long-term organizational activities created to enhance the implementation of organizational practices and individual behavior conducive to maintaining or improving employee physiological, mental, and social wellbeing (Wolfe \& Parker, 1994). The purpose of recreational programs in an organizational context is to promote the competency of manpower by improving their health. More recent studies conducted at Johnson \& Johnson (Fielding, 1994) also indicated positive opportunity costs, business-unit-wide, of health promotion programs. Joint Committee on Health Education Terminology has defined health promotion as the total of all focused activities created to enhance individual and communal health through several approaches, including behavior change strategies, health education, health protection measures, risk factor identification, health enhancement and health care (Goliath, 2007). All of these studies found recreational program effects normal exercise involvement, fitness levels, patients' medical costs, employee satisfaction, smoker quit rates and productivity. A recreational program promotes outstanding health to the employee, and it is organized purposely to upscale the quality of life in the workplace.

Recreational programs can be seen as a preprogram that require action in achieving the health promotion among manpower at workplace. A review by Travellers' Insurance Company health promotion programs reported a decrease in health claims, absenteeism and life insurance costs; an enhancement in productivity; and a return on investment of approximately US $\$ 3.40$ for every US $\$ 1.00$ spent (Golaszewski \& Yen, 1992). According to Penang Motorola in-house clinic annual report, total disaster from March to December 2005 was 24490 cases (Annual Medical Report [ASP], 2005). Among those cases, three severe cases were Hypertension (stress), Diabetic Mellitus, and Thyroid (hormone) problems. Psychological burdens will affect physical health particularly employees' lifestyle. In year 2005, the recreational programs in Motorola able to reduce absenteeism rate for 12 percent within six months (ASP, 2005). As a result, Motorola has actively implemented the recreational activities in previous years' results.

Since health problem is true become a big constraint for employees to perform well in their work; therefore, corporate, recreational programs are vital to lead workers to have healthy life. It is a challenge to human resource to instil these elements within the employees in order to generate a positive judgment on recreational programs. Contributions of recreational programs on employees are seen as a return of labor cost by organization.

\subsection{Importance of Recreational Programs}

Recreational program is a way to stop the bleeding in health care costs (Long, 2007). Implementing employee recreational programs will able to create a win-win situation between the employer and employees with reduced tangible cost in the area of healthcare, disability, absenteeism, and compensation, learning on how to create a healthy lifestyle and how to be safe on job respectively (Bates, 2006). "Twenty-five percent of what you spend on health care every year is something we can change through wellness; the tools, the programs, that is what's going to affect your bottom line," said Dr Terry Fouts, senior vice president for Great-West Healthcare (Long, 2007). This means recreational programs can assist a company to enjoy lower costs and greater financial savings, by retaining superior employees without affecting human resource, which has been seen as essential to a company. The employee who chooses to retain in one company can be said as he/she is satisfied with his/her job.

The most critical issue often being asked is the effectiveness of the recreational programs. Several studies have been conducted to identify the contributions of recreational towards both employee and employer. Most of their studies focused on independent characteristics, health care cost, recreational programs variables, absenteeism rate, stress level, job satisfaction and reflection from employees that could lead to effective health promotion at the workplace. Bates (2006) stated that some researcher enforce that indirect cost of poor condition that is absenteeism may be two or three times higher than the direct medical costs (Wellness Proposal, 2006). This means an indirect cost due to low productivity is one of the major concerns of most of the employers. Chapman (1999), cited in Wellness Proposal (2006) found that worksite health promotion and recreational programs can reduce sick leave by 27.8 percent, reduce health cost by 28 percent, reduce disability costs by 33.5 percent, reduce workers compensation costs by 33.5 percent and save $\$ 5.50$ in cost for every dollar invested.

Some researchers have tried to show a central play of recreational programs. For example, according to Johnson \& Johnson studies, he also indicated positive opportunity costs, business-unit-wide of health promotion programs (Fielding, 1994). From his study, positive effects on recreational programs were found in regular exercise participation, fitness levels, patients' medical expense, employee satisfaction, smokers' quit rates and on 
an indirect measure of productivity. Besides that, Connors (1992) found that some companies have enjoyed intangible benefits such as improved employee morale, health and productivity, employee attraction and retention, and improved image for corporations.

In addition, recreational programs results in fewer injuries, less human error and harmonious work environment besides increases employees' morale and retains key people. Moreover, when employees know that their company is concerned about their health and wellness, this would indirectly increase their loyalty and satisfaction. According to Bates (2006), employee recreational programs can result in financial saving in the following four areas (Wellness Proposal, 2006):

- Reduction in demand for medical services

- Reduction in employee absenteeism

- Reduction in on-the-job injuries and worker's compensation costs

- Reduction in disability costs

In short, recreational programs can be considered as an effective method to lower employee related costs and build up their personal relations within a company

\section{Job Satisfaction}

Job satisfaction is a topic that concerned by both the people, those who are working in organizations and for people who study them. It is the variable which is studied most frequently in organizational behavior studies, and it is also a fundamental variable in both research and theory of organizational experience range from job design to supervision (Hong, Li \& Robinson, 2005), including psychology, public administration, business and higher education (Kh Methle, 2005). The principal reason of why job satisfaction is so extensively researches is that it relates to significant associations with several variables; it has a positive association with life satisfaction, organizational commitment, job performance (Buitendach \& De White, 2005), organizational performance and employee satisfaction (Kim, Tang \& Tang, 2005).

Maslow's Hierarchy of Needs Theory was one of the first that proposed a relationship between need fulfillment and job satisfaction. It had five essential needs; physiological needs, including food, water, air, etc; safety needs including freedom from physical threat and harm, and economy security; belongingness and care needs which are two-fold for mastery and achievement as the need for recognition. In some extents, job satisfaction is what employee feels and perceived about its job and what are their experiences on work, whether they feel positive or negative about job (Kim et. al., 2005; Williams, 2007), or whether they are satisfied with their present work due to how many their needs and wants are being satisfied (Tsiotsou, 2001). Yang (2009) and Al-Hussami (2008) agreed that job satisfaction resulting from a feeling of pleasure in doing a job.

\subsection{The Consequences of Job Satisfaction}

Numerous authors have highlighted that job satisfaction impacts on employee productivity, turnover, absenteeism, physical and psychological health as stipulated in Table 1.

Table 1. The consequences of job satisfaction

\begin{tabular}{lll}
\hline \multicolumn{1}{c}{ Author/s } & \multicolumn{1}{c}{ Variables } & \multicolumn{1}{c}{ Findings } \\
\hline Johns (1996) & Productivity & $\begin{array}{l}\text { Indicate that the relationship between job satisfaction } \\
\text { and productivity is positive, but very low and } \\
\text { inconsistent. } \\
\text { Luthans (2002) }\end{array}$ \\
Robbins (2003) & $\begin{array}{l}\text { Physical and psychological } \\
\text { health }\end{array}$ & $\begin{array}{l}\text { Turnover } \\
\text { experience better mental and health } \\
\text { Turnover is inversely related to job satisfaction. }\end{array}$ \\
Luthans (1989) & Absenteeism & $\begin{array}{l}\text { Relationship between job satisfaction and absenteeism } \\
\text { indicates an inverse relationship between the two } \\
\text { variables. Thus, when satisfaction is low, absenteeism } \\
\text { tends to be high. }\end{array}$ \\
&
\end{tabular}

\subsection{Dimensions of Job Satisfaction}

One of the most comprehensive and widely used measures for job satisfaction is presented by Wood, Lawrence and Shelby, (1986) and Purani and Sahadev (2008). In this study, job satisfaction is characterized as a multidimensional and it has six key facets; namely) satisfaction with supervisor, ii) satisfaction with variety, iii) 
satisfaction with closure, iv) satisfaction with compensation, v) satisfaction with co-workers, and vi) satisfaction with management and HR policies.

\section{1) Satisfaction with Supervisor}

According to Wood et al. (1986), this facet of the job satisfaction determines the level of job satisfaction on the basis of employees' perception on how much are they satisfied with the information or guidelines provided to them by their supervisors to carry out their job.

\section{2) Satisfaction with Variety}

Satisfaction with multiplicity is another facet of job satisfaction, whereby employees perceive the level of satisfaction challenging but not regular. This also helps them to recognize that there are many chances for them to succeed in the organization. Furthermore, this area also measures the employee awareness of job satisfaction through the level of perceived freedom in job.

3) Satisfaction with Closure

Satisfaction with closure is the dimension of perceives job satisfaction, which determines how an employee perceives his/her job as a source of opportunity that provides him/her enough time to complete the work from start to finish.

\section{4) Satisfaction with Compensation}

Compensation is one of the most external indicators of job satisfaction which identify job satisfaction level of employees; how much they are satisfied with the wages or compensation or any other security their jobs provided to them. Churchill (1979) considered compensation as one of the dimensions of job satisfaction among sales people satisfaction. With the compensation plan, it would inevitably affect a sales person's predisposition to leave.

\section{5) Satisfaction with Co-workers}

Satisfaction with co-workers is the scope of perceived job satisfaction, which determines how an employee perceives his/her task attainment by the support or the presence of his/her coworker's attitude and behavior such as selfishness, helpful or supportive (Keyoor et al., 2008).

6) Satisfaction with Management and HR Policies

A major facet of job satisfaction that emerged from Purani and Sahadev's research (2008) reveals several factors that relates with the overall satisfaction towards human resources policies and strategies in one company. This is often verbalized in terms of such statements like "This company always acts for the well being of its employees" or the "I am satisfied with the general working conditions". Purani and Sahadev (2008) argued that while issues like supervisory behavior and indemnification form part of the micro issues regarding a sales person's involvement with the organization, the overall policies and strategies regarding the workforce is associated with a macro stance with regard to the individual's evaluation of the organization. For instance, if the overall policies of the organization with respect to workers are not paralleled with supervisory style, he/she may be inclined to leave.

Analysis of data and the reporting of the results of those analyses are fundamental aspects of the conduct of research. Accurate, unbiased, complete, and insightful reporting of the analytic treatment of data (be it quantitative or qualitative) must be a component of all research reports. Researchers in the field of psychology use numerous approaches to the analysis of data, and no one approach is uniformly preferred as long as the method is appropriate to the research questiqns being asked and the nature of the data collected. The methods used must support their analytic burdens, including robustness to violations of the assumptions that underlie them, and they must provide clear, unequivocal insights into the data.

\section{Relationships between Recreational Program and Job Satisfaction}

Job satisfaction has become a serious concern in the workplace. According to Janice (1997) in previous studies indicated that the level of employees health considerably affected by job satisfaction. Interest in job satisfaction is particularly notable because of its consequences for the organization, such as absenteeism and turnover (Cherrington, 1989) and for the employee, such as mental and physical health (O'Donnell \& Ainsworth, 1984). Thus, it can be suggested that a highly satisfied employees will be beneficial for organizations. Research has shown that employees with improved morale are likely to be more productive; as a result of, an increased sense of responsibility to the employer, and overall job satisfaction (Shinew \& Crossley, 1988).

The question, then, is whether having access to recreational programs would be able to stimulate employees' 
morale sufficiently to result in higher job satisfaction. Companies such as General Electric and Johnson \& Johnson have been able to provide affirmation to this question. In 1987, for example, General Electric Company in Cincinnati, Ohio, USA served as host for a study to compare the benefits of employees' recreation involvement with those of employees' fitness participation. A total of 900 employees were selected randomly from the computerized personnel data to compare absenteeism and overall job satisfaction among different employees. Results indicated that employees participating at any level showed less absenteeism and higher job satisfaction than employees who did not participate at all (Janice, 1997). Thus, job satisfaction produces benefits for organization and employees Adams (2007). Research has shown that employees with improved morale are likely to be more productive and improved overall job satisfaction.

The validated importance of recreational programs on job satisfaction had lead to replication of further studies by other researcher as stipulated in Table 2 .

Table 2. Evidence of the relationships between recreational programs and job satisfaction

\begin{tabular}{|c|c|c|}
\hline Author/s & Title & Findings \\
\hline Albrittton C.A (2008) & $\begin{array}{l}\text { Women counsellor educators: } \\
\text { contributors to levels of job } \\
\text { satisfaction. }\end{array}$ & $\begin{array}{l}\text { Recreational program impact overall levels of } \\
\text { job satisfaction and overall levels. }\end{array}$ \\
\hline Adams C.K (2007) & $\begin{array}{l}\text { The relationship between Job } \\
\text { Satisfaction and relaxation } \\
\text { program }\end{array}$ & $\begin{array}{l}\text { Relaxation program are correlate positively with } \\
\text { the overall job satisfaction. }\end{array}$ \\
\hline Kirby (2006) & Communication Yearbook 35 & $\begin{array}{l}\text { Organization that offers employees personal } \\
\text { services (including recreational programs) } \\
\text { reported stronger relationships between job } \\
\text { satisfactions. }\end{array}$ \\
\hline Janice (1997) & $\begin{array}{l}\text { Corporate wellness programs in } \\
\text { Singapore: Effect on stress, } \\
\text { satisfaction } \\
\text { and absenteeism }\end{array}$ & $\begin{array}{l}\text { Corporate wellness programs are observed to be } \\
\text { beneficial for employee and organizational } \\
\text { wellbeing. The results of the study indicate that } \\
\text { wellness programs have a positive impact on } \\
\text { employees' attitude towards their companies, job } \\
\text { satisfaction and satisfaction with fringe benefits. } \\
\text { When the level of job satisfaction is high, the } \\
\text { levels of stress and employee wellbeing, but also } \\
\text { for organizational wellbeing. }\end{array}$ \\
\hline
\end{tabular}

\section{Leisure Satisfaction}

\subsection{The Concept of Leisure Satisfaction}

The concept of leisure is highly subjective because it relies heavily upon individual perceptions. Activities typically considered "leisure" may have remarkably different meanings and levels of satisfaction for various participants (Berg, Trost, Schneider \& Allison, 2001). It can be defined as the experiences that participants feel during the process of participating in leisure activities (Gao, 1995). In other words, leisure satisfaction is the fulfilling feeling physically and emotionally after participating in any leisure activity. Beard and Ragheb (1980) defined leisure satisfaction as the feeling of positive feedback, sensation and satisfaction after a leisure experience. According to Beard and Ragheb (1980), leisure satisfaction was the positive concept. In other words, one has to be aware of one's leisure choice, experiences and condition to be satisfied from it. Berg et al. (2001) classified leisure satisfaction as an additional variable.

Leisure satisfaction could also have a significant impact on whether an activity is related to relationship satisfaction. $\mathrm{Lu}$ and $\mathrm{Hu}(2005)$ discovered that many people found their leisure life to be more enjoyable than work, whereas Shank, Coyle and Kinney, (1986) believed that leisure and recreation improve the quality of life and maintain physical and mental health and well-being. Better leisure satisfaction leads to higher life satisfaction, the more frequently one participates in leisure activity the better leisure satisfaction one would have (Ragheb \& Griffith, 1982). Therefore, personal leisure satisfaction plays an extremely pivotal role in life satisfaction ( $\mathrm{Lu} \& \mathrm{Hu}, 2005)$.

There are three key elements in leisure activities; m Q Fotivation, satisfaction, and constraints (Tseng, 2006). Neulinger (1981), social psychologist, said that pure leisure can be achieved with high perceived independence 
and pure intrinsic motivation. For that reason, there are a tangible association between leisure satisfaction, recreational programs, and job satisfaction. Leisure activities itself enhances life quality in many ways, including the level of independents function, mental health, emotion, interpersonal relationship, physical relaxation, loge experiences, physical relaxation, life experiences, higher learning efficiency and better work performance (Chen et al., 2003).

\subsection{The Linkage between Leisure Activity and Leisure Satisfaction}

Leisure satisfaction is the positive perceptions or feelings that an individual forms, elicits and gains as a result of engaging in leisure activities and choices. An individual might get positive feelings of contentment and joy that result from the satisfaction of needs. In general, leisure satisfaction refers to the actual thought or belief that an individual forms, elicits or even gains as a result of engaging in leisure (Shank et al., 1986). Therefore, we might ask a question of what can contribute to leisure satisfaction.

The degree of leisure satisfaction can be said as the extent an individual is currently satisfied with their leisure experiences and activities. Several variables have been linked to leisure satisfaction, in particular, personality, leisure activity or participation, leisure interest, facilitators and constraints to leisure, as well as various field related satisfactions. Numerous authors agree that leisure is a reflection or extension of which we are our traits or hidden attributes (e.g., Lu \& Kao (2009b)).

Kelly (1990) identified that leisure as activities that one chooses to engage in which are not part of a job, family, or social duties. As depicted in Figure 2, recreation, recreational sport, play game and sport are types of leisure. Each of them has its own definition overlap nebulously.

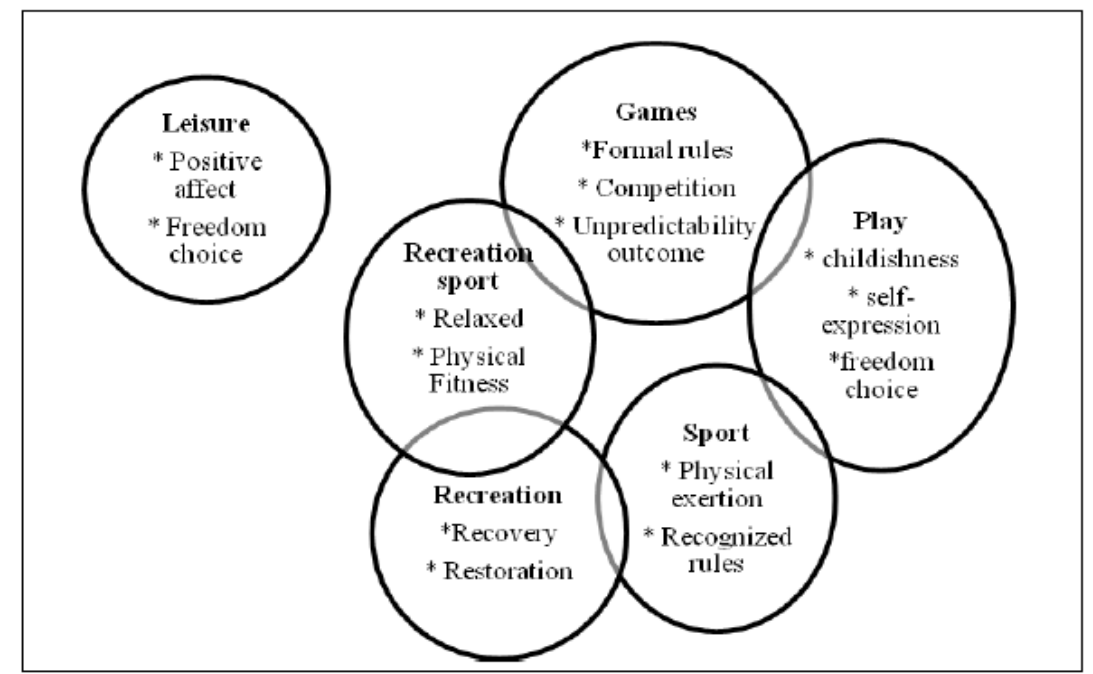

Figure 1. Relationship of leisure recreation, recreation sports, play, sport, and games as adapted from Chin S.W (2008)

Clearly, leisure activity has also been linked to leisure satisfaction. A study conducted by Lu and Kao (2009b) in which sex of participant, personality, and domain satisfactions (e.g., academic) were controlled for individuals who engaged in more leisure activities reported higher levels of leisure satisfaction. Other studies suggest that leisure activity also impacts such satisfaction based correlates as mood and happiness (Wijnallele et al., 2006).

\section{Conclusions}

This conceptual paper highlighted the relationship between recreational program and job satisfaction which emphasized on constructive literature review of the previous studies that scientifically proven the existence of this relationship in emergence of leisure satisfaction. Issues of job satisfaction were widely discussed from many aspects and its positive outcomes when organization successfully created satisfied environment. Further, a review of the literature provides a variety of perspectives on the relationships between recreational programs, leisure, and job satisfaction in several ways. First, many previous researches have worked on the relationship between leisure, recreational program and its effects towards different positive findings. A study by Cimete, at el. (2003) determined that job satisfaction also had a positive correlation with the quality of life, which active recreation had the prevalent correlation coefficients with the overall quality of life (Felce \& Perry, 1995). Second, the positive correlation of these three concepts will provide a better innovation in designing employer-supported 
recreaction program; therefore, it is crucial to provide types of program that economically and effectively benefit to participants. A remarkable program will be the cost-effective program that able to increase morale and retention (Morey, 1983). However, priority complex that exists in every human and different needs and wants based on Maslow's Theory of Needs indeed further researches are needed.

\section{Acknowledgements}

The author would like to convey thanks to the University of Sultan Zainal Abidin for providing the financial means and all facilities.

\section{References}

Adams, C. K. (2007). The relationship between job satisfaction and relaxation. Roosevelt University. ProQuest Dissertations and Theses. Retrieved January 4, 2012, from http://search.proquest.com/docview/304715776? accountid=48462

Albrittton, C. A. (2008). Missed work and lost hours. Monthly Labour Review, 109(11), 26-30.

Al-Hussami, M. (2008). A Study of Nurses' Job Satisfaction: The Relationship to Organizational Commitment, Perceived Organizational Support, Transactional Leadership. Journal of Scientific Research.

ASP Annual Medical Report. (2005). Motorola Wellness Program 2005. In Dayang et.al. (2007). A study on the relationships between corporate wellness programs and employees'stress, job satisfaction and absenteeism.

Bates, D. W. (2006). The state of regional health information organizations: Current activities and financing. Journal of Health Affairs, 27(1), 60-69.

Beard, J. G., \& Rahgeb, M. G. (1980). The leisure satisfaction measure. Journal of Leisure Research, 72(1), 20-33.

Berg, E., Trost, M., Schneider, I., \& Allison, M. (2001). Dyadic exploration of the relationship of leisure satisfaction, leisure time, and gender to relationship satisfaction. Leisure Sciences, 23, 35-46. http://dx.doi.org/10.1080/01490400150502234

Buitendach, J. H., \& De White, H. (2005). Job insecurity, extrinsic and intrinsic job satisfaction and affective organizational commitment of maintenance workers in a parastatal. South African Journal of Business Management, 36(2), 27-37.

Changsorn, P. (2010, October 10). Higher salaries and bonuses forecast. The Nation. Retrieved from http://www.nationmultimedia.com/home/2010/10/08/business

Chapman. (1999). The Associations between Life Satisfaction and Health-related Quality of Life, Chronic Illness, and Health Behaviors among U.S. Community-dwelling Adults. Journal of Community Health, 33(1), $40-50$.

Cherrington, D. J. (1989). Organizational Behavior. Boston, M.A.: Allyn and Bacon.

Chin, S. W. (2008). Why are adolescents addicted to online gaming? An interview study in Taiwan. Psychology \& Behavior, 9(6), 762-766.

Churchill, G. A. (1979). A paradigm for developing better measures of marketing constructs. Journal of Marketing Research, 16, 64-73. http://dx.doi.org/10.2307/3150876

Cimente, Gencalp, \& Keskin. (2003, April-June). Quality of life and job satisfaction of nurses. Journal of Nursing Care Quality, 18(2), 151-158. http://dx.doi.org/10.1097/00001786-200304000-00009

Connors. (1992). Leisure Activity, Life Satisfaction, and Perceived Health Status in Older Adults. Gerontology \& Geriatrics Education, 14(2), 23-36.

Felce, D., \& Perry, J. (1995). Quality of life: Its definition and measurement. Research in Developmental Disabilities, 16(1), 51-74. http://dx.doi.org/10.1016/0891-4222(94)00028-8

Fielding, J. E. (1994). The 'Live for life' program of Johnson \& Johnson: direct and indirect economic benefits, In Opatz, J. P. (Ed.), Champaign: Economic Impact of Worksite Health Promotion (pp. 209-228). Human Kinetics Publishers, IL.

Gao. (1995). All stressed up and no place to go. Modern Office Technology, 38(2), 27-28.

Golaszewski, T., \& Yen, L. T. (1992). Demographic characteristics of uses of worksite health promotion written materials. American Journal of Health Promotion, 6(5), 359-363. 
http://dx.doi.org/10.4278/0890-1171-6.5.359

Goliath. (2007). Report of the 2000 Joint Committee on Health Education and Promotion Terminology. Retrieved November 25, 2011, from http://goliath.ecnext.com/coms2/summary_0199-1581293_ITM

Hong, Y., Li, J. X., \& Robinson, P. D. (2005). Balance control, flexibility, and cardio respiratory fitness among older Tai Chi practitioners. British Journal of Sports Medicine, 34, 29-34. http://dx.doi.org/10.1136/bjsm.34.1.29

Janice, H. T. S. (1997). Corporate Wellness Programmes in Singapore: Effect on Stress, Satisfaction and Absenteeism. Journal of Managerial Psychology, 12(3), 177-189. Retrieved August 1, 2007, from Emerald database. http://dx.doi.org/10.1108/02683949710174801

Johns. (1996). Multiple Dimensions of Meaning in the Domains of Work, Family and Leisure. Journal of Leisure Research, 26.

Kelly. (1990). A theory of the attributes and causes of leisure experience. Journal of Leisure sciences, 13(1), $1-15$.

Kh Methle, M. (2005). The impact of education on attitudes of female government employees. The Journal of Management Development, 15(1), 47-67.

Kim, J. K., Tang, D. S. H., \& Tang, T. L. P. (2005). Does attitude toward money moderate the relationship between intrinsic job satisfaction and voluntary turnover? Human Relations, 53(2), 213-245.

Kinney, \& Coyle. (1999). Influences on Leisure and Life Satisfaction of Elderly People. Physical \& Occupational Therapy in Geriatrics, 15(4), 1-16. http://dx.doi.org/10.1080/J148V15n04_01

Kirby. (2006). Employee health management: challenges and opportunities. Academy of Management Executive, $8(2), 22-31$.

Long, A. (2007). Assessment of health-related quality of life in children with cancer. Cancer, 106, 2267-2274.

Lu, L., \& Hu, C. (2005). Personality, leisure experiences and happiness. Journal of happiness Studies, 6, 325-342. http://dx.doi.org/10.1007/s10902-005-8628-3

Lu, L., \& Kao, S. (2009b). Leisure Participation and Leisure Satisfaction: Moderating Effects of Personality Traits. Journal of Sport and Recreation Research, 3, 1-11.

Luo. L., (2011). Leisure Experiences and Depressive Symptoms among Chinese Older People: A National Survey in Taiwan. Educational Gerontology, 37(9).

Luthans, F. (1989). Organizational behaviour (5th ed.). New York: McGraw- Hill.

Luthans, F. (2002). Organizational behavior (9th ed.). New York: McGraw- Hill.

Morey, R. C. (1983). Cost-effectiveness of an employer-sponsored recreational program: A case study. Omega, 11(1), 67-74. http://dx.doi.org/10.1016/0305-0483(83)90085-3

Neulinger. (1981). The meaning of leisure in everyday life. Journal of Leisure sciences, 7(1), 1-24.

O'Donnell, M. P., \& Ainsworth, T. (1984). Health Promotion at the Workplace. New York: Wiley Medical.

Pearson, Q. M. (1998), Job Satisfaction, Leisure Satisfaction, and Psychological Health. The Career Development Quarterly, 46, 416-426. http://dx.doi.org/10.1002/j.2161-0045.1998.tb00718.x

Purani, K., \& Sahadev, S. (2008). The Moderating Role of Industrial Experience in the Job Satisfaction, Intention to Leave Relationship: An Empirical Study among Sales-men in India. Journal of Business and Industrial Marketing, 23(7) 475-485. http://dx.doi.org/10.1108/08858620810901239

Ragheb, M. G., \& Griffith, C. A. (1982). A behavioural model of leisure participation based on leisure attitude, motivation and satisfaction. Journal of Leisure Research, 14(4), 295-306.

Robbins, S. P. (2003). Organizational behaviour (6th ed.). New Jersey: Prentice Hall International.

Shank, J. W., Coyle, C. P., \& Kinney, W. T. (1986). Psychosocial functioning and changes in leisure lifestyle among individuals with chronic secondary health problems related to spinal cord injury. Therapeutic Recreation - psycnet.apa.org

Shinew, K. J., \& Crossley, J. C. (1988). A comparison of employee recreation and fitness program benefits. Employee Benefits Journal, 1, 13.

Tseng, C. C. (2006). A study on the job stress, leisure participation, leisure satisfaction and life satisfaction on 
the policemen. Unpublished Master thesis.

Tsiotsou, R., \& Vasioti, E. (2006). Using Demographics and Leisure Activities to Predict Satisfaction with Tourism Services in Greece. Journal of Hospitality \& Leisure Marketing, 14(2), 69-82. http://dx.doi.org/10.1300/J150v14n02_05

Wellness, P. (2006). John Bates: Companies Make Great Gains with Employee Wellness Programs. Retrieved November 12 , 2011, from http://www.wellnessproposals.com/wellness_articles/companies_make_great_gains_with_employee_wellne ss_programs.htm

Wijnallele, K., Matton, L., Duvigneaud, Lefevre, J., Bourdeaudhuij, I., Duquet, W., Thomis, M., \& Philippaerts, R. (2006). Association between leisure time physical activity and stress, social support and coping: A cluster-analytical approach. Psychology of Sport and Exercise, 8, 425-440.

Williams, J. (2007). Job satisfaction and organizational commitment. A Sloan Work and Family Encyclopedia entry. Retrieved May 10, 2007, from http://wfnetwork.bc.edu/encyclopedia_entry.php?id=244\&area= academics

Wolfe, R. A., \& Parker, D. F. (1994). Employee health management: challenges and opportunities. Academy of Management Executive, 8(2), 22-31.

Wood, V. R., Lawrence B. C., \& Shelby D. H. (1986). Social responsibility and personal success: Are they incompatible? Journal of Business Research, 14, 193-212. http://dx.doi.org/10.1016/0148-2963(86)90001-9

Yang, Y. (2009). Determinant of job satisfaction of federal government employees. Public Personnel Management, 26(3), 343-351.

Zeti, A. A. (2005). Opening speech at the Industry Competency Framework Study Focus Group Discussion at Renaissance Hotel, Kuala Lumpur. Retrieved January 15, 2012, from http://www.bnm.gov.my/index.php?ch=9\&pg=15\&ac=189 